\title{
The Prominence of Financial Considerations on Housing Investors' Purchase Decisions
}

\author{
Radyan DANANJOYO $^{1}$, Fitra Roman CAHAYA ${ }^{2}$, Hosam Alden RIYADH ${ }^{3}$ \\ Received: August 01, 2020 Revised: November 02, 2020 Accepted: November 16, 2020
}

\begin{abstract}
As a basic element for sustainable development, the residential housing industry is vital and fundamental for every country in the world. Therefore, this study examines the impacts of financial considerations on house purchase decisions by housing investors in Auckland, New Zealand. 110 completed questionnaires were statistically analyzed. For testing the proposed hypotheses, Structural Equation Modelling (SEM) was used. The results show that house prices, income, and credit accessibility significantly influence housing investors' purchase decisions in a positive direction. It appears that more expensive houses offer more promising returns such that housing investors having higher levels of income and access to loans are brave enough to invest in such houses. This study aims to present the key factors influencing house purchase decisions from the viewpoint of housing investors as fundamental groups of stakeholders in the property market, which is rarely examined in previous studies. The implication of this study is to provide guidelines for housing regulators in New Zealand to develop affordable housing prices through the availability of land banks. This study also offers practical contributions to housing investors, particularly by providing key guidelines to make effective investment decisions.
\end{abstract}

Keywords: Financial Considerations, Investors, Residential Housing, Purchase Decision

JEL Classification Code: L1, P23, P42

\section{Introduction}

As a basic element for sustainable development, the residential housing industry is vital for every country in the world (Hoda et al., 2020). In many countries, the main objective of housing policy is to support private homeownership. Having a house is a primary need for the house owner; a majority of communities save a major portion of their income to purchase or construct a brand new house or for renovating their existing house (Jeon, 2018).

${ }^{1}$ First Author and Corresponding Author. Business and Economics Faculty, Universitas Muhammadiyah Yogyakarta, Indonesia [Postal Address: Jl. Brawijaya, Tamantirto, Kec. Kasihan, Yogyakarta, 55183, Indonesia] Email: radyan.dananjoyo@umy.ac.id

${ }^{2}$ Business and Economics Faculty, Universitas Islam Indonesia, Yogyakarta, Indonesia

${ }^{3}$ Business and Economics Faculty, Universitas Muhammadiyah Yogyakarta, Yogyakarta, Indonesia

(c) Copyright: The Author(s)

This is an Open Access article distributed under the terms of the Creative Commons Attribution Non-Commercial License (https://creativecommons.org/licenses/by-nc/4.0/) which permits unrestricted non-commercial use, distribution, and reproduction in any medium, provided the original work is properly cited.
Nevertheless, housing affordability becomes a crucial concern, and housing prices in major urban communities have skyrocketed to unreasonable price levels (Nguyen et al., 2020). Such problems are also present in New Zealand, a developed nation that is one of the major destinations of immigrants from around the world. The main problem in the housing market in New Zealand is a lack of stock, causing a sharp rise in the prices. The housing market in this country, particularly in big cities like Auckland, is therefore regarded as being the most unreachable marketplace on the planet. Under these conditions of unreasonable price levels, housing in Auckland is marked by the excessively high cost of housing, which is 8.8 times the salary of family units (Cox \& Pavletich, 2018).

The housing industry is one of the important industries contributing to the development of a nation's economy (Nguyen \& Do, 2020). Wright and Yanotti (2019) stated that investment in residential housing is the largest and most crucial investment. Over recent years, the residential house prices in New Zealand have been at the highest ever, triggering problems for new house buyers to afford owning a house. There are three kinds of stakeholders in the property market namely homeowners, speculators, and investors (Sean \& 
Hong, 2014). Normally, investors buy a house to generate financial returns and they expect capital appreciation when renting their house. Speculators mean people who buy a house for a short-term investment, expecting to create huge profits. Homeowners are those who buy a house for private use and usually reside in the property (Wright \& Yanotti, 2019).

Currently, transactions in the housing market in New Zealand are dominated by investors. $45 \%$ of the annual housing transactions are from investors, followed by $28 \%$ of people moving to other places, $19 \%$ of annual transactions are first home buyers, and $8 \%$ of annual transactions are other investors (Statistics New Zealand, 2019). New Zealand house prices are still on the rise; these rises have driven up the national average, which is now also at its highest ever point. Presently, the house prices have risen to a staggering $\$ 695,116$, whereas 12 years ago, the average price was only $\$ 410,000$ (Taylor, 2019). Therefore, financial considerations are a profoundly crucial factor to decide when buying a home for clients $(\mathrm{Si}$, 2012). Purchasing a house is one of the most noteworthy economic choices, which major individuals take. . Rational and irrational factors are the factors underlying the property (house) buying process. The physical, location, finance, and environment are rational factors, while psychological, emotional, intuitional, socialization, and evaluation are irrational factors (Anastasia \& Suwitro, 2015).

There have been only limited studies focusing on residential housing investors in New Zealand. The investigation of the residential sector mostly considers the general homeowner's perspective (Hui et al., 2019; Abreu et al., 2020; Nguyen, 2020). This research aims to give a comprehension of critical factors influencing housing purchase decisions from the housing investors' perspective in the New Zealand residential housing industry. The results of the study would be significant to housing investors, giving them a better understanding of the housing purchase decision. Besides, scholars may gain further knowledge about financial factors affecting investors' housing purchase decisions, a focus of research that has been ignored in previous studies.

The remainder of the paper is arranged as follows. The subsequent section presents the literature review. Section 3 explains the hypotheses development. Section 4 discusses the research method and section 5 discusses the findings. The final section of the study presents the conclusion and some recommendations for future studies.

\section{Literature Review}

\subsection{Housing Investors}

This study chooses the Auckland housing market as the research setting because Auckland is the financial capital of New Zealand and has the largest population in the nation. The population of Auckland is 1,695,900 or one-third of the total population in New Zealand (Statistics New Zealand, 2019). Auckland is classified as the ninth-least reasonable city worldwide to live in (Cox \& Pavletich, 2018). At present, the Auckland housing market has experienced excess demand. The critical factors causing excess housing demand in Auckland are steady population growth, lowinterest rates, a robust national economy, and Auckland's status as the primary financial focal point of New Zealand (Wetzstein, 2019).

In a residential housing market, housing investors are identified as investors who purchase a house driven by an investment decision and expect capital gain from their purchase. Housing investors purchase numerous estates and they do not reside in those estates. Usually, housing investors will speculate regarding the housing rate due to the rapid development of housing prices. The speculation from the housing investors will trigger an increase in house prices in the market. Investors actively search and bargain to purchase and sell their properties. Therefore, the main goal of housing investors is purchasing a house as the best investment alternatives against other types of assets. Investors purchase a house as an investment to earn capital gains in the future. Besides, investors expect capital appreciation from their property investment (Tan, 2009).

At the moment, Auckland is the hottest housing market in the world (Collinson, 2016). Since Auckland has the largest population in New Zealand, many people want to purchase a house as an investment. However, Auckland is facing a housing crisis. Auckland's housing supply has not kept pace with increases in population or met demand for investment, creating the current housing crisis. In the past, around $37 \%$ of housing purchasers were homeowners but nowadays, approximately $50 \%$ of housing buyers are investors (Roy, 2016). Many New Zealanders cannot buy a house in Auckland and have to relocate to a more affordable place outside Auckland.

\subsection{Financial Considerations}

It is evident from the literature that financial considerations influence decisions to buy products or services (Hamilton et al., 2019). In terms of residential housing, the financial considerations for investors when purchasing a house are house prices, income, and credit accessibility (Roidoung, 2013). Housing price is to be counted as the point of balance, in which the ability to compensate for a home fulfills the eagerness to sell a house (Qin \& Han, 2013). House prices could be categorized as one of the key determinants of house ownership affordability (Galster \& Lee, 2020), implying that changes in house prices influence the investment decisions of investors. A house price itself is affected by several factors, for instance, speculative pressure, supply condition of mortgage market innovation, and demographic 
development. Previous studies' findings showed that house prices are impacted by population, construction cost, and housing speculation (Mariadas et al., 2016).

Price is a critical component that decides the capacity of investors to buy a house. The vast majority of the people cannot buy a house that is priced exorbitantly. From 2003 to 2017, for instance, house prices in Auckland increased by $172 \%$ or $7.44 \%$ per year. In New Zealand nationwide, the price increase was $139.5 \%$ or equivalent to a $6.85 \%$ annual growth rate (Statistics New Zealand, 2019). Housing demand in Auckland has shown increases along with house prices, creating benefits for investors while pushing other homeowners further out of the market.

The investor's income level decide housing purchase decisions. Investors' income can be depicted as the whole of wages and pay rates, government transfers, self-employment income, and other earnings (purchased annuities, registered retirement savings plans, retirement pensions, and retirement earning funds), minus taxes paid (Lafrance, \& LaRochelleCote, 2011). It may be even the sum of cash earning of each source, for instance, earnings of the labor market from selfemployment and employment, savings, salary as well as investment, private and occupational pensions, added by all-cash advantages from the government such as retirement pensions reduced by social security contributions and direct income taxes. Income has a significant role for every investor who desires to buy or construct a house. Investors should make a detailed analysis to have a suitable income allocation. The total income also affects the quality of houses purchased by investors.

A continuous increase in house rates in New Zealand is considered a huge issue among New Zealanders, especially in Auckland. Research shows that housing ownership demand is primarily influenced by the growth of population, formation tariffs of households, the prices of houses, and the growth of earning (Flavin, 2002). Among these factors, a recent study by Ceritoğlu (2020) uncovers that earning is the primary basis of house rights. In line with Ceritoğlu's (2020) finding, homeownership levels in Auckland have decreased because house prices in this city have increased higher than Aucklanders' incomes.

On the contrary, investors could earn a passive income through their property investment if they can afford to invest in housing. There are three kinds of housing investors: active, passive, and portfolio (Cortesi, 2016). Investment in the residential housing market requires great effort since investors should have knowledge, skills, and power to determine the appropriate property, and be able to manage the property until they find a buyer. Thus, house investment can be described as a financial investment in which a person buys a house based on his/her financial capability.

The price of the property is affected by credit accessibility, and the property demand increases if credit is increasingly available. Moreover, to decide the investors' ability to access bank credit or another financial agency, the Loan-to-Value Ratio (LVR) is also crucial. In New Zealand, the reserve bank has presented LVR limitation for housing loans since October 2013. The policy's primary objective is to aid the growth pace of credit related to housing and house rate inflation, with the fundamental purpose of diminishing the risk of a significant downward correction of house prices, which would negatively affect the housing sector. The limitation was utilized as a 'speed-limit' in which banks could create high loans of LVR (over $80 \%$ of the home estimation) equal to $10 \%$ of their new mortgage loans for over three months (Rogers, 2014).

Credit interest rates, as stated by Booysen (2013), will potentially decline if credit is increasingly available. Such a decline triggers present and future activities in the economic field. New Zealand can be categorized as having high levels of household debt. $30 \%$ of new borrowers get mortgages more than six times their incomes. As property prices in Auckland have been increasing, a clean credit record is identified as a crucial aspect in gaining access to a loan.

\subsection{Purchase Decision}

A purchase decision could be described as a continuous process of thought and action that is reliable and carried out to realize the needs of satisfaction (Shareef et al., 2008). A purchase decision can even be depicted as a social, situational, individual, and perceived contextual phenomenon (Blackwell et al., 2006). Throughout the decision-making process, investors and buyers examined in this study, determine whether to purchase, when to purchase, what to purchase (the house type and quality), where to obtain the house (the house location), and determine how to pay. This research specifically investigates the impacts of financial considerations in determining housing investors' purchase decisions.

\section{Hypotheses Development}

Based on the above discussion, this study hypothesizes three independent variables to examine their potential impacts on housing investors' purchase decisions. The hypothesized independent variables are house price, income, and credit accessibility. The hypotheses for these variables are presented in the following hypotheses statements.

H1: There is a significant relationship between house prices and house purchase decisions.

H2: There is a significant relationship between income and house purchase decisions.

H3: There is a significant relationship between credit accessibility and house purchase decision. 


\section{Research Methods}

This study applies a quantitative research approach as it examines hypotheses. Such an approach is considered appropriate for this study because all variables investigated in this research were calculable and quantifiable. The perceptions of investors toward the attributes of financial consideration were obtained through a survey to build up an appropriate financial consideration measurement. A questionnaire survey was thus employed so that data from a large number of respondents could be obtained (Saunders et al., 2019).

There were two segments in the questionnaire. The first part contained the background information, presenting the respondents' characteristics. The subsequent segment comprised opinions of the investors, including the questions related to purchasing decisions, house price, credit accessibility, and income. In this study, the questionnaire employed a six-point Likert scale to quantify the attitudes. Usually, in research when a questionnaire is used to evaluate the attitudes of the respondents, the Likert scale is used in the forms of a psychometric scale. The scale in this study consisted of three positive responses and three negative responses. A six-point scale is used to obtain more reliable answers since a six-point scale gives more options to respondents compared to a five-point scale (Creswell, 2014). The use of a six-point scale itself can avoid neutral responses. Previous studies related to the choice of housing also used a six-point scale for similar reasons (Fierro et al., 2009). 250 questionnaires were distributed but only 110 questionnaires were returned, indicating a rate of response of $44 \%$.

To clarify linear combinations of dependent variables, the major goals of analysis in this study were forming a linear combination among the observed and latent independent variables (Tabachnick \& Fidell, 2013). Therefore, the primary analytical technique used in this research was the Structural Equation Modelling (SEM). It calculated the causal connection between observed variables (one or more factors that were directly measured) and latent independent variables (one or more factors that were not directly measured) (Jodie, 2006). Scrutinizing the relations among the latent variables (unobservable), including house price, income, credit accessibility, and purchase decision, was the essential focus of this study. The methodology of SEM is valuable in social and behavioral sciences, in which a significant number of variables are imperceptible.

In a multivariate analysis, statistical assumptions consisting of normality, outliers, homoscedasticity, and linearity are needed to be examined to ensure that fundamental information assumptions were met for validity and statistical conclusions. As such, this study checked these assumptions through different statistical tests. In addition to the classical assumption check, this study employed an Analysis of Moment Structures (AMOS) to efficiently and precisely design and examine the interconnection between the latent variables (Byrne, 2016).

\section{Result and Discussion}

Table 1 displays the results of the descriptive statistics concerning critical factors of the purchase decision attribute. It indicates that the investors identified all the attributes related to house purchase decision as significant factors (for example, a mean score of $>4.0$ ). Besides, house price was recognized by the investors as a very significant factor.

To categorize the 'important' and 'most important' attributes, t-test analysis was employed. It started by comparing the null hypothesis $\left(\mathrm{H}_{0}\right): \mu_{1}<\mu_{0}$ and the alternative hypothesis $\left(\mathrm{H}_{1}\right): \mu_{1}>\mu_{0}$, in which $\mu_{1}$ signifies the population means as well as $\mu_{0}$ denotes the critical rating. In this study, the $\mu_{0}$ value was expressed as " 4 " since it indicated the statements of "slightly agree," "mostly agree," and "completely agree" in the questionnaire. When the observed $\mathrm{t}$-values $\left(\mathrm{t}_{0}\right)$ are higher than the critical $\mathrm{t}$-value $\left(\mathrm{t}_{\mathrm{c}}\right)$, the null hypothesis $\left(\mathrm{H}_{0}\right)$ is not supported. The $\mathrm{t}_{0}$ and $\mathrm{t}_{\mathrm{c}}$ formulation is as follows: (Wong \& Li, 2006)

$$
\begin{array}{ll}
\mathrm{t}_{0}=\frac{\chi-\mu_{0}}{\sigma / \sqrt{\eta}} \quad \mathrm{t}_{\mathrm{c}}=\mathrm{t}_{(\eta-1, \alpha)} \\
\mathrm{t}_{0}=\text { observed } \mathrm{t} \text {-values } & \mathrm{t}_{\mathrm{c}}=\text { critical } \mathrm{t} \text {-value } \\
\sigma=\text { standard deviation } & \chi=\text { sample mean } \\
\eta=\text { sample size } & \alpha=\text { significant level, } 5 \% \\
\mu_{0}=\text { critical rating } & \eta-1=\text { degree of freedom } \\
\eta=\text { the size of the sample } &
\end{array}
$$

For this study, the critical $t$-value $\left(t_{c}\right)$ was described as $\mathrm{t}_{(413,0.05)}=1.984$. It implies the null hypothesis $\left(\mathrm{H}_{0}\right)$, in which "completely disagree," "mostly disagree," and "slightly disagree" attributes were not supported. Thus, only the alternative hypothesis $\left(\mathrm{H}_{1}\right)$ was supported. Moreover, in finding out the critical factors, the t-value was employed by contrasting the critical t-value $\left(\mathrm{t}_{\mathrm{c}}\right)$ and the observed $t$-values $\left(t_{0}\right)$. Table 2 shows the critical values based on a threshold of $t_{c}$. Therefore, house price was the most significant factor for the house purchase decision.

Table 1: Descriptive Statistics of the Attributes of House Purchase Decision

\begin{tabular}{|l|c|c|c|c|c|}
\hline $\begin{array}{l}\text { Attributes } \\
\text { of Purchase } \\
\text { Decision }\end{array}$ & Min & Max & Mean & Median & $\begin{array}{c}\text { Std. } \\
\text { Deviation }\end{array}$ \\
\hline House Price & 1 & 6 & 5.18 & 5 & 0.96 \\
\hline Income & 1 & 6 & 4.86 & 4 & 1.12 \\
\hline $\begin{array}{l}\text { Credit } \\
\text { Accessibility }\end{array}$ & 1 & 6 & 4.82 & 5 & 1.15 \\
\hline
\end{tabular}


In this study, factor loading, Average Variance Extracted (AVE), and Composite Reliability (CR) needed to be taken into account to measure reliability and validity. Build upon the variance level chosen by the construct in contrast to the measurement error level, AVE measurements could be performed. If the value is 0.5 , it is classified as good. Then, it is considered as very good if the value is 0.7 or higher. Whereas, to compare the construct of error variance and factor loading, CR was utilized. The value of the cut-off of CR was 0.7 , meaning that it was higher than the acceptable value for $\mathrm{CR}$. The correlation of each variable was measured by factor loading to estimate the indicators according to the latent variables. A sufficient convergence between the variables in the construct was showed by $\geq 0.5$ values of factor loading. In this study, the factor loading value was mostly higher than 0.5 , meaning that there was a constructive relationship between each variable, as shown in Figure 1.

In estimating purchase decision, the critical ratio of house price (CR) was 4.075, while the p-value was 0.010, as in Table 3 . The CR threshold was $\geq 1.984$ classified as significant, while the $p$-value cut-off was $\leq 0.05$ considered as significant.

Table 2: The Attributes of Critical Factor

\begin{tabular}{|l|c|c|c|}
\hline $\begin{array}{l}\text { Purchase Decision } \\
\text { Attributes }\end{array}$ & Mean & Std. Deviation & t-value \\
\hline House Price & 5.18 & 0.96 & 25.010 \\
\hline Income & 4.86 & 1.12 & 15.624 \\
\hline Credit Accessibility & 4.82 & 1.15 & 14.508 \\
\hline
\end{tabular}

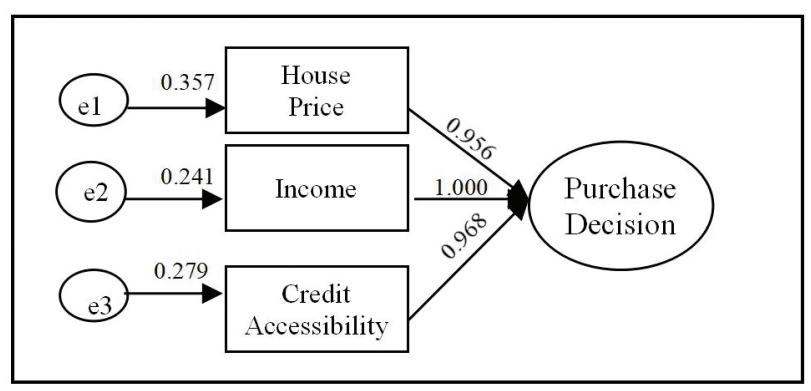

Figure 1: The Model of Overall Measurement with Standardized Factor Loadings
It indicates that the $\mathrm{H} 1$ hypothesized parameter was accepted. It can be assumed that house prices positively affected the purchase decision of investors.

The p-value and CR for H2 were 0.023 and 2.372, as seen in Figure 1 and Table 3. The CR threshold was more than 1.984 and classified as significant, while the p-value cut-off was less than 0.05 and classified as significant. It could be stated that $\mathrm{H} 2$ was in the hypothesized direction and statistically significant. Hence, it supported $\mathrm{H} 2$ which predicted that income affected the decision to purchase. The p-value and CR, which were 0.023 and 2.372 respectively, revealed that 0.023 was the possibility of gaining critical value in the absolute value of 2.372. It can be stated that, statistically, income significantly affected the purchase decision of the investors. In verifying purchase decision, the credit accessibility for p-value and CR were respectively 0.012 and 3.923 . It means that $C R$ was more than 1.984 and classified as significant, while the p-value cutoff was less than 0.05 and classified as significant. It can be stated that H3 was accepted, stating that the purchase decision was affected by credit accessibility.

The leading objective of this study was to cope with the problem of property over-demand in Auckland. The investor's ability to buy a home was one of the primary problems. The results of this study reveal that house prices are extremely important to determine an investor's purchase decision, as shown in Table 2. In this study, most of the respondents tried to make sure of the price before deciding to purchase a house.

\section{Conclusion}

This study shows that house prices, income, and credit accessibility positively influence investors' purchase decisions. House price, income, and credit accessibility measurements are critical insights for investors in the Auckland housing industry (an extremely important research setting for residential housing in New Zealand). Therefore, housing investors in Auckland should gain a better understanding of financial considerations as a basis for making the best investment decisions. Better knowledge of financial considerations will prompt investors to make better housing investment decisions. The findings of this study provide a clearer picture for housing investors to find which housing areas are more profitable for their businesses.

Table 3: Hypothesis Testing

\begin{tabular}{|l|c|c|c|c|c|}
\hline Dependent Variable & Predictors & Estimate & S.E. & C.R. & P-value \\
\hline \multirow{3}{*}{ Purchase Decision } & House Price & 0.332 & 0.020 & 4.075 & 0.010 \\
\cline { 2 - 6 } & Income & 0.125 & 0.021 & 2.373 & 0.023 \\
\cline { 2 - 6 } & Credit Accessibility & 0.134 & 0.053 & 3.923 & 0.012 \\
\hline
\end{tabular}


The main contribution of this study is the establishment of essential guidelines to develop effective housing investment decision strategies. Housing investors having higher levels of income and access to loans decide to invest in more expensive houses since such houses offer more promising returns in the future.

A significant finding in this study is the relationship between financial considerations and investors' purchase decisions. To foresee the housing gap in New Zealand, housing regulators are required to create housing plans based on market needs. Based on the result of this study, housing demand is derived from complex matrices that reflect price, income, and credit accessibility. It needs more effort from regulators to provide housing at an affordable price. One of the critical factors that led to high housing prices in New Zealand is the unavailability of affordable land.

Like most empirical studies, some limitations exist in this research. First, this research only included and concentrated on the contribution of "newly-built" housing investors in Auckland. The purchase decisions of second-hand housing investors were not examined in this study. Second, this study only focused on housing purchases. The decision-making process of house purchase comprised five steps: problem introduction, information seeking, alternative evaluations, purchasing decisions, and post-purchase decision behavior. Third, this research was mainly concerned with house prices, income, and credit accessibility. Future studies should therefore examine second-hand housing investors' purchase decisions, other aspects of the purchase decision-making process such as information seeking, and other possible independent variables. Future studies should also investigate speculators' perspectives in the residential sector.

\section{References}

Abreu, M. I., de Oliveira, R. A. F., \& Lopes, J. (2020). Younger vs. older homeowners in building energy-related renovations: Learning from the Portuguese case. Energy Reports, 6, 159164. https://doi.org/10.1016/j.egyr.2019.08.036

Anastasia, N., \& Suwitro, A. L. (2015). The rational and irrational factors underlying property buying behavior. Journal of Economics and Behavioral Studies, 7(2), 183-191. https://doi. org/10.22610/jebs.v7i2(J).576

Barrett, P. (2007). Structural equation modeling: Adjudging model fit. Personality and Individual Differences, 42(5), 815-824. https://doi.org/10.1016/j.paid.2006.09.018

Blackwell, R. D., Miniard. P. W., \& Engel, J. F. (2006). Consumer behavior (10th ed). Mason, OH: South-Western Thomas Learning.

Booysen, C. (2013). Credit growth, asset prices, and financial stability in South Africa: A policy perspective. Doctoral dissertation, North-West University.
Byrne, B. M. (2016). Structural equation modeling with AMOS: Basic concepts, applications, and programming. England, UK: Routledge. https://doi.org/10.4324/9780203805534

Ceritoglu, E. (2020). Homeownership, housing demand, and household wealth distribution in Turkey. Emerging Markets Finance and Trade, 56(5), 1146-1165. https://doi.org/10.1080 /1540496X.2018.1555461

Collinson, P. (2016). New Zealand tops world house prices increase. Retrieved from https://www.theguardian.com/money/2016/ sep/06/new-zealand-tops-world-house-price-list.

Cortesi, G. R. (2016). Mastering real estate principles (7th ed). US: Dearborn Real Estate Education.

Cox, W., \& Pavletich, H. (2018). 14th Annual demographic international housing affordability survey 2017. Belleville, IL: Demographia, 1-51.

Creswell, J. W. (2014). Research design: Qualitative, quantitative, and mixed methods approach (4th ed). Thousand Oaks, CA: Sage Publications.

Fierro, K. P., Fullerton, T. M., \& Donjuan-Callejo, K. E. (2009). Housing attribute preferences in a Northern Mexico metropolitan economy. Atlantic Economic Journal, 37(2), 159172. https://doi.org/10.1007/s11293-009-9174-x

Flavin, M. (2002). Owner-occupied housing and the composition of the household portfolio. The American Economic Review, 92(1), 345-362. https://doi.org/10.1257/000282802760015775

Galster, G., \& Lee, K. O. (2020). Housing affordability: A framing, synthesis of research and policy, and future directions. International Journal of Urban Sciences, 8(12) 1-52. https:// doi.org/10.1080/12265934.2020.1713864

Hamilton, R. W., Mittal, C., Shah, A., Thompson, D. V., \& Griskevicius, V. (2019). How financial constraints influence consumer behavior: An integrative framework. Journal of Consumer Psychology, 29(2), 285-305. https://doi.org/10.1002/ jcpy. 1074

Hoda, N., Jafri, S. A., Ahmad, N., \& Hussain, S. M. (2020). Empirical testing of a house pricing model in the Indian market. Journal of Asian Finance, Economics, and Business, 7(8), 3340. https://doi.org/10.13106/jafeb.2020.vol7.no8.033

Hui, E. C. M., Chen, J., \& Chan, K. K. K. (2019). House Hedging Model - Which income group is more affected by risk? Physica A: Statistical Mechanics and its Applications, 529, 121537. https://doi.org/10.1016/j.physa.2019.121537

Jeon, J. H. (2018). The impact of Asian economic policy uncertainty: Evidence from the Korean Housing market. Journal of Asian Finance, Economics, and Business, 5(2), 43-51. https://doi. org/10.13106/jafeb.2018.vol5.no2.43

Jodie, B. U. (2006). Structural equation modeling: Reviewing the basics and moving forward. Journal of Personality Assessment, 87(1), 35-50.

Lafrance, A., \& LaRochelle-Cote, S. (2011). Consumption patterns among aging Canadians: A Synthetic Cohort approach. Perspectives on Labour and Income, 23(2), 1-12. 
Mariadas, P. A., Selvanathan, M., \& Hong, T. K. (2016). A study on housing prices in Klang Valley, Malaysia. International Business Research, 9(12), 103-109. https://doi.org/10.5539/ibr. v9n12p103

Nguyen, C. N. (2020). Homeowners' choice when the government proposes a managed retreat. International Journal of Disaster Risk Reduction, 47, 101-103. https://doi.org/10.1016/j. ijdrr.2020.101543

Nguyen, H. C., \& Do, D. T. (2020). factors influencing the perception of the selling price of luxury apartments. Journal of Asian Finance, Economics, and Business, 7(5), 185-194. https://doi.org/10.13106/jafeb.2020.vol7.no5.185

Nguyen, H. M., Phan, H. Q., Tran, T. V., \& Tran, T. K. V. (2020). The Hedonic method in evaluating apartment price: A case of Ho Chi Minh City, Vietnam. Journal of Asian Finance, Economics, and Business, 7(6), 517-524. https://doi.org/10.13106/jafeb.2020. vol7.no6.517

Qin, B., \& Han, S. S. (2013). Emerging polycentricity in Beijing: Evidence from housing price variations, 2001-05. Urban Studies, 50(10), 2006-2023. https://doi.org/10.1177/0042098012471979

Rogers, L. (2014). An A to $\mathrm{Z}$ of loan-to-value ratio (LVR) restrictions. Reserve Bank of New Zealand Bulletin, 77(1), 3-14.

Roidoung, P. (2013). Factors of housing decisions for low and middle-income households in the greater Bangkok area. The Empirical Econometrics and Quantitative Economics Letters, 2(3), 13-26.

Roy, E. A. (2016). Why Auckland is the hottest property market in the world. Retrieved from https://www.theguardian.com/ world/2016/sep/07/why-auckland-is-leading-the-worldshousing-market-booms

Saunders, M., Lewis, P., \& Thornhill, A. (2019). Research methods for business students (8th ed). London, UK: Pearson Education Limited
Sean, S. L., \& Hong, T. T. (2014). Factors affecting the purchase decision of investors in the residential property market in Malaysia. Journal of Surveying, Construction, and Property. 5(2), 1-13. https://doi.org/10.22452/jscp.vol5no2.4

Shareef, M. A., Kumar, U., \& Kumar, V. (2008). Role of different electronic-commerce (EC) quality factors on purchase decision: A developing country perspective. Journal of Electronic Commerce Research, 9(2), 92-113.

Si, P. T. (2012). Key factors affecting house purchase decisions of customers in Vietnam. Master Thesis, University of Economics Ho Chi Minh City, Ho Chi Minh City, Vietnam.

Statistics New Zealand. (2019). Property transfer statistics: September 2019 quarter. Retrieved from https://www.stats. govt.nz/information-releases/property-transfer-statisticsseptember-2019-quarter

Tabachnick, B. G., \& Fidell, L. S. (2013). Using multivariate statistics $\left(6^{\text {th }} \mathrm{ed}\right)$. London, UK: Pearson.

Tan, T. H. (2009). Homeowning motivation in Malaysia. Journal of Accounting, Business, and Management, 16(1), 93-112. https:// mpra.ub.uni-muenchen.de/id/eprint/34906

Taylor, V. (2019, February 1). Average New Zealand house price reaches an all-time high. Retrieved from http://www.newshub.co.nz

Wetzstein, S. (2019). Comparative housing, urban crisis, and political economy: An ethnographically based 'long view' from Auckland, Singapore, and Berlin. Housing Studies, 34(2), 272297. https://doi.org/10.1080/02673037.2018.1487038

Wong, J., \& Li, H. (2006). Development of a conceptual model for the selection of intelligent building systems. Building and Environment, 41(8), 1106-1123. https://10.1016/j. buildenv.2005.04.021

Wright, D., \& Yanotti., M. B. (2019). Home advantage: The preference for local residential real estate investment. PacificBasin Finance Journal, 57, 101167. https://doi.org/10.1016/j. pacfin.2019.06.014 